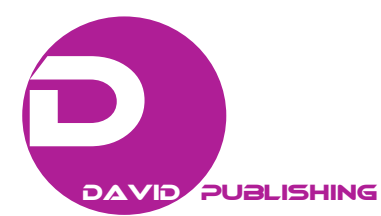

\title{
The Roses of Durham
}

\author{
Olin L. Adams III and Rebekah Keenon \\ Auburn University, Auburn, Alabama 36849, United States of America
}

\begin{abstract}
This paper recalls the 1942 Rose Bowl game, which was relocated from its traditional site at Pasadena, California, to Duke University in Durham, North Carolina. The Tournament of Roses nearly cancelled the game after a government request to avoid large crowds on the West Coast, in light of the Japanese attack on Pearl Harbor. Duke, originally selected as the visiting team to play Pacific Coast Conference champion Oregon State University, resolved the dilemma by offering to stage the game at its campus stadium. Duke Stadium had a capacity of only 35,000, much smaller than the Rose Bowl stadium, and 20,000 temporary seats from nearby University of North Carolina and North Carolina State University were added to accommodate fans. On the strength of a 13-point third quarter, Oregon State upset undefeated Duke, 20-16, in the 28th Rose Bowl game. The game returned to Pasadena the following year. With Allied victory at the Battle of Midway and stabilization of the Pacific Theater of war, the West Coast was considered secure enough to host large events. The move of the 1942 Rose Bowl was the first of many impacts on sport generally and college football in particular caused by World War II. With male enrollment reduced drastically, many colleges and universities did not field a football team for one or more seasons during the war. Prominent players were killed in action, including some who competed in the 1942 Rose Bowl. Coaches likewise joined the war effort, notably Wallace Wade of Duke. Following the war, the readjustment of servicemen extended to the gridiron, as football rosters included many veterans. Yet the 1942 Rose Bowl has new relevance beyond its 75 th anniversary. The 2008 Southeastern Conference men's basketball tournament was moved when a tornado struck Atlanta. In 2015 terrorists attacked a soccer stadium in Paris, raising new consciousness of the global threat of terrorism. Sport managers strive to make events safe, not only at the venue, but within an expanding perimeter.
\end{abstract}

Key words: Intercollegiate athletics, sport history, Rose Bowl, World War II, contingency management.

On Sunday, December 7, 1941, Japan severed diplomatic relations with the United States and shortly before 8 a.m. local time staged a surprise attack to American armed forces at Pearl Harbor in Hawaii, destroying much of the Pacific fleet. Calling the events "a day that will live in infamy", President Franklin D. Roosevelt asked the following day for a declaration of war from Congress, which obliged with near unanimity. The isolationism into which America had relapsed following World War I was reversed, this time for good.

\section{The Transplanted Rose Bowl}

During December the Japanese offensive advanced into the Philippines, notably Luzon, and Malaya, including Singapore. These moves raised concern in America that Japan's territorial ambitions could turn

Corresponding author: Olin L. Adams III, Ph.D., associate professor, research field: sport management. east to the west coast of the United States. Military leaders notified Governor Cuthbert Olson of California in the matter of President Roosevelt's view that the west coast was vulnerable. Olson, in turn, sent a telegram to the Tournament of Roses, stating: "The unusually large gathering of people known to the enemy, exposing them to the dangers now threatening, requires that plans for holding of this tournament and football game be abandoned." [1].

William Wallace Wade had played guard at Brown University, appearing in the second Rose Bowl game, which marked the end of a 14-year hiatus from the gridiron for the Tournament of Roses. The tournament had abandoned the sport after its first contest, called the Tournament East-West game and matching Michigan and Stanford, had been so dominated by the Wolverines that it was called in the third quarter. In the interim chariot racing had complemented the annual Tournament of Roses Parade in Pasadena. 
Wade returned to the Rose Bowl a decade after his appearance as a player, in 1926 as head coach of the University of Alabama. This marked the first time a Southern team had competed in the game, and undefeated Alabama defeated Washington 20-19. The following year Wade and Alabama were back, tying Stanford 7-7. After three seasons with three or more defeats and harsh criticism for losing to Tennessee and head coach Robert Neyland, Wade accepted the position of head football coach at Duke University. However, in a move incomprehensible today, he honored the final year of his Alabama contract and led his team back to the Rose Bowl, completing a perfect season with a 24-0 win over Washington State.

Wade's Duke teams won three Southern Conference championships in his first seven seasons at Durham, but the breakout year came in 1938 when his "Iron Dukes" were undefeated and ranked third in the nation. Duke was invited to the 1939 Rose Bowl, the fourth for Wade as a coach, but fell 7-3 to Southern California. When Duke was again undefeated and ranked second three years later, the Blue Devils were the choice of Pacific Coast Conference champion Oregon State as its opponent in the 28th Rose Bowl.

Although Chicago, Washington, D.C., and Dallas offered to host the transient 1942 Rose Bowl game [1], Wade had a different idea: move the game to Duke University. While the majestic Rose Bowl stadium, at 86,000 capacity, dwarfed Duke Stadium, with 35,000 seats, the Durham facility was the third largest campus stadium in the South. Only Tulane Stadium in New Orleans, site of the Sugar Bowl, at 73,000, and Tiger Stadium in Baton Rouge, Louisiana, at 50,000, accommodated more fans. Moreover, Duke Stadium was comparable to two other facilities for major bowl games, the Cotton Bowl in Dallas, with 48,000 seats, and Orange Bowl in Miami, with 40,000 [2]. Finally, the capacity of Duke Stadium could be increased by 20,000, with temporary bleachers borrowed from the University of North Carolina and North Carolina State University. Only a week after the attack on Pearl
Harbor, the Tournament announced the move of the game to Durham [3].

Duke players understood the reason for holding the game in their stadium, but nonetheless were disappointed at forfeiting the trip to California [4]. The team also was ambivalent about using the last holiday before military service to prepare for and play in a game [3]. On a first vote the Duke players rejected the bowl bid, but after some persuasion, accepted on a second vote [1]. Wade gave his team the week off before Christmas, which he later regretted.

Issues of race also were observed in preparation for the game. Duke customarily provided segregated seating for Blacks, a loyal contingent of fans, at home games. The university initially refused to continue this practice for the Rose Bowl game, but reversed its decision when a report revealed an administrator would sell tickets to Japanese [4]. Agents from the Federal Bureau of Investigation confronted Oregon State football player Jack Yoshihara at practice and informed him he would not be permitted to travel to Durham. Yoshihara soon left college and was confined to an internment camp in Idaho [1].

Oregon State, ranked 12th nationally after a 7-2 regular season, traveled east by train, with stops in Chicago for practice and Washington for sightseeing [1]. The team arrived in North Carolina on Christmas Eve and stayed at the Carolina Inn in nearby Chapel Hill. Although a 13-point underdog, Oregon State "Coach Lon Stiner still contended that his coast champions would do more than make an appearance on the field. He and his players-all 31 of them-were ready and confident that Duke is on the verge of a rude upset" [5].

The famed sports writer Grantland Rice waxed poetic and optimistic in his game preview:

There is keen interest all over the south-as well as the far west - in the transplanted Rose Bowl game, shifted from Pasadena to Durham.

No one doubts that Durham will go all out in making this transfer stand up - not in the way of any 90,000 
attendance, but in other details that Pasadena cannot quite match. Rose Bowls are old stories to Pasadena. This game will be a much bigger thrill in its new North Carolina setting, apart from the game itself [6].

\section{The 28th Rose Bowl}

On New Year's Day, Thursday, January 1, 1942, the Rose Queen and her princesses traveled Colorado Boulevard in Pasadena, void of spectators, before a ceremony with 33 miniature floral floats was held at the Huntington Hotel [1]. Across a continent, game day in Durham brought cold rain and fog, likely making Oregon State feel at home. Duke fumbled the opening kickoff, a portent of ill for the Blue Devils. Oregon State could not capitalize on the mistake, as its drive stalled at the Duke 14. However, late in the first quarter the Beavers made a fourth down gamble pay, after which Don Durdan ran 15 yards for the game's first touchdown. Warren Simas converted for a 7-0 lead. Duke responded with a 70-yard drive following an Oregon State fumble. Steve Lach carried the final four yards, and Bob Gantt's point after touchdown squared the game at 7-7, the halftime score [7].

Oregon State regained the lead on a 32-yard pass from Bob Dethman to George Zellick and the ensuing Simas conversion. Duke answered with a drive highlighted by Lach's 48-yard run to the Beavers 25 . Lach gained eight more yards before a penalty on Oregon State moved the ball to the one-yard line. A plunge by Winston Siegfried and the kick, this time by quarterback Tommy Prothro, tied the game, 14-14. The Beavers closed the third quarter with another touchdown, a 68-yard strike from Dethman to Gene Gray. When Duke blocked Simas' kick, the score remained 20-14. Early in the fourth quarter the teams traded interceptions, then Lach punted to the Oregon State three. Attempting to punt from the end zone, the Beavers' Durdan fumbled the snap and was tackled by Duke's Tom Burns for safety. Duke threatened, but could not score. The Devils' last gasp ended in an interception by Dethman, a two-way hero. Oregon
State upset Duke, 20-16. The Blue Devils committed seven turnovers: four passes intercepted, three fumbles lost. Oregon State, better suited to the conditions, was intercepted twice and lost one fumble [7].

\section{Sport in War}

The move of the 1942 Rose Bowl was the first of many impacts on sport generally and college football in particular caused by World War II. Two days after the Rose Bowl game at Durham, the most prestigious college football all-star game, the East-West Shrine Game, was held at Tulane Stadium in New Orleans. Traditionally staged at Kezar Stadium in San Francisco, the 1942 game ended in a 6-6 tie, beset by the same sodden weather that plagued the Sugar Bowl on New Year's Day during a 2-0 win by Fordham over Missouri. Only two years removed from the triumph of Seabiscuit in the 1940 Santa Anita Handicap, Santa Anita Park cancelled its winter 1942 Thoroughbred racing meet. In the wartime environment fans at sporting events were subject to searches similar to those of today. At the 1942 Sugar Bowl, Harry Reilly, chief clerk of the New Orleans police, inspected a large package brought by a fan. Reilly found 24 cans of beer in the package. After opening two cans to confirm the contents were beer, the fan was allowed to proceed into Tulane Stadium with the remaining 22 unopened cans [8].

With male enrollment reduced drastically, many colleges and universities did not field a football team for one or more seasons during the war. In 1942 most major colleges competed in football, albeit sometimes with an abbreviated schedule. After Allied victories that year in the battles of Midway and Guadalcanal, stabilizing the Pacific Theater of war, the west coast was considered secure enough to host large events. The Rose Bowl returned to its Pasadena home for the 1943 game, a 9-0 win by Georgia over first time participant UCLA.

However, with mobilization of troops for the European Theater of war, male enrollment plummeted 
in 1943, as did college football participation. The Big Ten, Southern (much of today's Atlantic Coast Conference), Big Six, and Southwest conferences, as well as Notre Dame, Army, and Navy, competed in football throughout the war. Among members of the Southeastern Conference, then but a decade old, only Georgia, Georgia Tech, LSU, and Tulane, fielded a football team in 1943. In the Pacific Coast Conference, just four universities competed in football that year: California, Southern California, UCLA, and Washington. With the dearth of teams available, the Rose Bowl on New Year's Day 1944 staged its only intraconference matchup in the game's 103 years, pairing Southern California and Washington (information is from World Almanac, 1944).

During the war, football teams were organized within the armed forces, filling the void left by the colleges. Along with Army and Navy, these service teams dominated college football. Navy and four service teams finished in the top ten of the final Associated Press poll of the 1943 season. The following year Army, Navy, and four service teams accounted for six places in the top ten. Randolph Field played in the Cotton Bowl on New Year's Day 1944, tying Texas 7-7, and finished the next season ranked third in the nation [2]. While all members of the Southeastern Conference other than Vanderbilt restored football by the autumn of 1944, the Pacific Coast did not return to substantially full participation until 1945 [2].

The United States achieved complete commitment to the war effort. As the bowl games were played on New Year's Day 1942, the closing of car and truck manufacturing was announced. This permitted full utilization of industry resources for the war. In fact, the entire gross domestic product of the nation was dedicated to the war effort. Consistent with this focus, prominent athletes served in World War II. Having batted 406 the prior summer, Ted Williams of the Boston Red Sox underwent his physical examination for induction a scant five days after the 1942 Rose
Bowl [9]. Angelo Bertelli of Notre Dame was drafted in the middle of the 1943 football season, his team undefeated after six games. A Marine in boot camp at Parris Island, he listened to Notre Dame's final game, a last minute loss to Great Lakes Naval Training and the only defeat of the season. Then Bertelli received a telegram informing him he had won the Heisman Trophy for his partial season of play [10]. Bertelli lived to age 78. Nile Kinnick of Iowa, the 1939 Heisman Trophy winner, was not so fortunate. A scholar athlete who was elected to Phi Beta Kappa, he enlisted in the Naval Air Corps Reserve after completing the first year in law school. Kinnick was killed at age 24 in 1943 during a training flight off the coast of Venezuela. Four players who competed in the 1942 Rose Bowl game, three from Duke and one from Oregon State, also were killed in action during the war [1].

Coaches likewise joined the war effort. Following the loss in the 1942 Rose Bowl game, Wallace Wade entered military service. Bernie Bierman, head football coach at the University of Minnesota (national champions in 1940 and 1941), was called to duty by the Marine Reserves in January 1942. Similarly activated by the Army was L. M. (Biff) Jones, head football coach at the University of Nebraska [9]. Robert Neyland, head football coach at the University of Tennessee, was recalled by the Army even before Pearl Harbor and served from 1941 to 1945, primarily in the China-Burma-India Theater. Neyland also had stepped away from coaching for one year in peacetime, 1935, during active duty in Panama. Elevated to the rank of brigadier general for his distinguished service in World War II, Neyland thereafter was known less as Coach Neyland than General Neyland.

When the war ended in 1945, the Servicemen's Readjustment Act of the prior year, known colloquially as the GI Bill, promised higher education to returning veterans, and college enrollment swelled. Football rosters included many veterans, but few so remarkable as Alvin Wistert. Born in 1916, Wistert spent a dozen years working in a factory and serving in the United 
States Marine Corps during the war. Under the GI Bill, he entered Boston University in 1946 as a 30-year old freshman and tackled on the football team. Wistert transferred to the University of Michigan, where he became the oldest college football player ever to earn all American honors, a distinction he was accorded at age 32 in 1948 and again at age 33 in 1949.

\section{Duke and Oregon State: Athletic Legacy}

Both Duke and Oregon State have achieved their greatest athletic notoriety in men's basketball. Duke has reached the Final Four of the NCAA basketball tournament 16 times. The first three appearances came under coach Vic Bubas, in 1963, 1964, and 1966. The Blue Devils played in the championship game in 1964, falling to UCLA, as the Bruins won the first of 10 titles in a dozen years. Coached by Bill Foster, Duke was back in the final in 1978. However, the greatest era in Duke basketball is in progress. Mike Krzyewski, in his 37th season as coach, has won five NCAA championships (1991, 1992, 2001, 2010, and 2015), finished as runnerup four times (1986, 1990, 1994, and 1999), and reached the semifinal round three other times (1988, 1989, and 2004). Although intrastate rival Oregon won the first NCAA championship in 1939, Oregon State enjoyed success under coach Amory T. "Slats" Gill. The Beavers advanced to the NCAA Final Four in 1949 and 1963, the penultimate season in Gill's 36 years as coach.

Notwithstanding their accomplishments on the hardwood, both Duke and Oregon State found gridiron glory after the 1942 Rose Bowl. With Eddie Cameron filling in for Wade during the war, the Blue Devils won the 1945 Sugar Bowl. Upon his return, Wade could not recapture his prewar success and retired following the 1950 season. Bill Murray succeeded Wade and built a similarly impressive record, leading Duke to two Orange Bowls, a win in 1955 and a loss in 1958, as well as a victory in the 1961 Cotton Bowl. The latter appearance earned Duke the distinction of one of the first five universities to play in all four major bowl games (Alabama, Georgia Tech, and Tennessee preceded Duke; Navy achieved the honor on the same day). After Murray, Duke's gridiron star declined, but the Blue Devils made one curtain call under Steve Spurrier. In his last of three seasons as coach, Duke shared the 1989 ACC championship with Virginia.

Tommy Prothro, who played quarterback at Duke and kicked the Blue Devils' second point after touchdown in the 1942 Rose Bowl, later coached rival Oregon State from 1955 to 1964. Prothro served as an assistant coach to Henry (Red) Sanders at Vanderbilt for three years and UCLA for six before moving to Corvallis. Led by Heisman Trophy winning quarterback Terry Baker, Oregon State won the 1962 Liberty Bowl. Baker also played point guard on the Beavers' NCAA Final Four basketball team the following March. Prothro led Oregon State to the 1965 Rose Bowl game, a lopsided loss to Michigan, in his final game as the Beavers' coach. The following year he was back in Pasadena, coaching UCLA to its first win in the Rose Bowl. Oregon State would not reach another high profile bowl until 2001. Coached by Dennis Erickson, the Beavers routed Notre Dame in the Fiesta Bowl, 41-9.

\section{Implications}

The 1942 Rose Bowl has new relevance beyond its 75th anniversary. Citizens began to understand that their lives equal casualties to enemies. They realized that enemy success would depend on the common man's destruction. The public became the target. The immediate result for the sporting world was the move of the Rose Bowl to the east coast. However, many years would pass before citizens made worrying about their safety, outside wartime, a daily thought.

The terrorist attacks of September 11, 2001, delayed seasons in multiple sports, not merely to observe a period of mourning, but to secure venues for competitors and spectators.

The 2013 Boston Marathon endured a terrorist attack, as did a Paris soccer stadium in 2015. The attack at 
Boston served notice to sport managers that an expanding perimeter was their responsibility. In addition to terrorism, natural disasters can threaten the safety of spectators at sporting events. The third game of the 1989 World Series was postponed 10 days after an earthquake struck San Francisco. The 2008 Southeastern Conference men's basketball tournament was moved when a tornado damaged the Georgia Dome in Atlanta. The tournament resumed the next morning, albeit with a limited crowd, at Alexander Coliseum on the Georgia Tech campus.

The case of Steering Committee v. Port Authority of New York and New Jersey (51 A.D. 3d 337, 856 N.Y.S. 2d 583 Supreme Court of New York [11] has influenced those responsible for public safety, including sport managers. The plaintiffs contended that the World Trade Center (WTC) had prior knowledge of problems in securing the property. In 1984 the Port Authority recognized that it needed to create the Office for Special Planning (OSP) to address the problems of terrorism around the world that might affect the WTC. This office found that the parking deck below the WTC was "vulnerable to attack by a car bomb". However, the Port Authority rejected all remedial measures that had been suggested. Nine years later, the OSP's fears were substantiated. This case in premises liability demonstrates that organizations must look past known security risks and into future security challenges.

How do organizations balance cost, implementation of security, and the expectations of the public? What does this look like when put into action? Two touchstones for organizations that hold large sporting events have been the creation of government standards and security models for implementation in large sports arenas. The Department of Homeland Security, the Federal Bureau of Investigation (FBI), and state agencies provide guidelines for prevention of and preparation for natural disasters, terrorist attacks, and facility failures. Sport managers have taken these guidelines and created models for implementation of security at large sport facilities. Most security models used by sport managers contain the following: risk assessment, training, exercise, validation. Security managers must balance the implementation and cost of security models. While they understand their responsibility, the cost of security at major sporting events can go into the billions.

For the Super Bowl this year, the planning for security began three years ago when Houston made the bid for holding the event. Home of the Houston Texans, the NRG Stadium was guarded by a legion of law enforcement agencies. Baddour (2017) reviewed the security plans for the day. The sport managers collaborated with "more than 20 federal agencies", local law enforcement, the FBI, and the Federal Aviation Agency. The city alone estimated expenditures of $\$ 5.5$ million over a 10 -day period around the Super Bowl [12]. The Super Bowl is an outlier to other events, however, it serves as an example to sport managers as to the expectations of patrons regarding their personal safety. Sport managers in the situation of the Super Bowl or the Olympics can collaborate with federal agencies to secure the premises, and the cost is shared by all involved. This is not the case for other large sporting events. In those cases, sport managers work with facility and security personnel to secure the stadium, arena, or baseball diamond, but the cost of security comes from the budget of a single organization.

For three quarters of a century, Americans have pursued their lives substantially undeterred by mounting risk. Yet since the roses of Durham, they have known that, even at play, it is a dangerous world.

\section{References}

[1] Baddour, D. 2017. "Agencies Collaborate on Super Bowl 51 Security." Houston Chronicle.

[2] Dawidoff, T. N. 1987. "A Half-Season Heisman.” Sports Illustrated.

[3] Bombs? No, Beer! 1942. Atlanta Constitution.

[4] Martin, J. 1942. "Duke, 3-to-1 Favorite, Faces Confident Oregon." Atlanta Constitution.

[5] Martin, J. 1942. "Oregon State Beats Duke, 20-16, before 
56,000." Atlanta Constitution.

[6] Rice, G. 1942. "200,000 Fans Will See Dixie Bowl Games Today." Atlanta Constitution.

[7] Steering Committee v. Port Authority of New York and New Jersey (51 A.D. 3d 337, 856 N.Y.S. 2d 583) (Supreme Court of New York).

[8] Ted Williams Receives Orders for Physical Exam on Tuesday. 1942. Atlanta Constitution.

[9] The Durham Rose Bowl. 1942. http://library.duke.edu/rubenstein/uarchives/history/articl es/rose-bowl.

[10] "The World Almanac and Book of Facts (1943, 1944, 1945, 1946)." New York World Telegram.

[11] West, W. F. 2007. "Duke Hosted Rose Bowl: After Pearl Harbor There Were Fears of a West Coast Attack by the Japanese." The Herald-Sun (Durham, North Carolina), 28.

[12] Wharton, D. 2016. "The Day the Rose Bowl Was Played 2,500 Miles from the Rose Bowl." Los Angeles Times. Reprinted by the Hamilton Spectator (Ontario, Canada), S5. 